\title{
Attitude Towards Language in Sociolinguistics Settings: A Brief Overview
}

\author{
Ahmad Amin \\ Department of English Education, STKIP Muhammadiyah Barru, Indonesia \\ ahmadamin093010@gmail.com
}

ARTICLE HISTO
$\begin{array}{ll}\text { Received } & : 2020-03-04 \\ \text { Revised } & : 2020-03-15 \\ \text { Accepted } & : 2020-04-03\end{array}$

\section{KEYWORDS}

Language

Language attitude

Language behaviour

Sociolinguistics

\begin{abstract}
The use of language is a form of social interaction that occurs in various situations. Social interaction will live from the activity of talking to members of the language users. Language is also a means to show self-identity. Through language, we can show our viewpoint, our origins and nations, our education level, even our nature. This study uses a sociolinguistic perspective to analyse the language attitude in multilingual society, as it is an interesting phenomenon to study. Language behaviour and attitude towards language are the two things that are closely related, which can determine the choice of languages as well as the survival of a language. The study of sociolinguistics is addressing the phenomena of language selection as a discourse in the event of communication and demonstrating the social and cultural identity of the speech participants. Community members are constantly changing variations in the use of language.
\end{abstract}

\section{Introduction}

Language is one of the human characteristics that differentiate them from another creature. Besides, language has a social function, either as a communication device or as a way of identifying the social group. De Saussure stated that language is one of the institutions of society, which is same as other community agencies, such as marriage, inheritance, and so on (Chaer \& Agustina, 2004). It has signalled the importance of attention to the social dimension of language. Ronald Wardhaugh defined language as a system of arbitrary vocal symbols used for human communication (Mesthrie, Swann, Deumert, \& Leap, 2000).

The use of language is a form of social interaction that occurs in various situations. Language patterns and language skills as well as language behaviours vary in the speech communities (Brenzinger, 2017). Social interaction will live from the activity of talking to members of the language users. The talk activity will be more successful if it is supported by other factors that also determine, such as attitude and the situation (Jabeen, 2011).

According to Keraf (1997), as a means of communication, language is a formulation channel of our intentions. It produces our feelings and allows us to cooperate with others. It arranges several social activities, plans and directs our future. When we use language to communicate, we already have a specific purpose. We want to be understood by others and we want to convey the idea that can be accepted by others. This interest in language as used in actual contexts of communication has included consideration of the embodied way in which people communicate and gather together (Mondada, 2016). Language is also a means to show self-identity. Through language, we can show our viewpoint, our origins and nations, our education level, even our nature. Language reflects ourselves, both as a nation and a self (Elyana, 2012). Language is considered an important tool for communication as it is capable of affecting many people and their behaviour.

However, awareness about the close relationship between language and society just emerged in the middle of this century (Hudson, 1985). The linguists began to realise that studying language without associating it with the society would rule out some important and interesting aspects, perhaps even shortened the vision of the discipline of the language itself.

Language choice is typically born as a result of the use of language in a bilingual or multilingual society (Marwa, 2014). In the selection of languages, committing a mistake in choosing a variety of language that fits with the relevant situation of communication cannot easily be avoided. The mistake can cause a loss for the participant of communication. Even people with advanced level of native and foreign language can experience difficulties in multicultural contexts (Derin, Nursafira, Yudar, Gowasa, \& Hamuddin, 2020; Kondrateva, Madakina, Sigal, \& Valeev, 2016). Therefore, in this paper, the attitude towards language in sociolinguistics will be investigated. This study is expected to be useful in providing insight into the communication phenomena in the multilingual community. 


\section{Method}

This study used a descriptive analysis to explore the language attitude and language behaviour toward language in sociolinguistics perspective which discusses about the linguistics phenomenon as a topic the case of communication and reveals the social and cultural identity of the speaker.

The researcher used several references from relevant articles and books to support the discussion further. It will also explain what is implied by attitude toward language and the language; how the relation to language selection.

\section{Discussion}

Sociolinguistics put the language as part of the social system, communication system, and a part of a certain community and culture. (Fatmanuraini, 2011). The use of language is a form of social interaction that occurs in various situations. The social interaction will keep continuing if there is talk activity among the users of the language.

Sociolinguistics is the study of the language with the social dimension (Ferguson, 1999). Verhoeven (2017) also added that sociolinguistic skills allow the person to deal with daily language situations. When we learn a language without referring the language to people who use it, that is equal to eliminate the possibility of finding a social explanation for the structure used (Downes, 1984). From the sociolinguistic perspective, language attitude in multilingual society is an interesting phenomenon to study, because the attitude towards a language can determine the survival of the language (Jabeen, 2011).

Language is a means to show self-identity that has a social function. Mesthrie et al. (2000) stated that language has sometimes been seen as reflecting preexisting social divisions and social values. It may suggest a kind of social determinism: that people speak as they do. Alternatively, language has been seen as relatively powerful, constraining its speakers' thoughts and beliefs.

According to Kridalaksana (2001), to understand with more detail regarding the definition of language, people can be it from two aspects, namely technical aspect and practical aspect. Technically, language is a set of meaningful utterance produced by human's vocal organs. Meanwhile, language in a practical aspect is a communication tool among the members of society that is a meaningful sound system that the linguistic community uses in their everyday lives.

The attitude of the language is a crucial matter in relation to a language (Elyana, 2012). It is because the attitude on the language can continue the language life. The topics of language attitudes, however, are not only varieties of language and their speakers, but it may also be both social and psychological problems related to language usage in life (Santello, 2013). The following will discuss what is meant by attitude toward language and how the relation to language selection.

The word 'attitude' can refer to a position of the body, feeling or opinion about something, and action towards a case or incident (Dictionary). Attitude is a psychological phenomenon, which is usually manifested in the form of action or behaviour (Kartomiharjo, 1988). Attitudes cannot be observed directly. According to Anderson, attitudes can be seen through behaviour, but various studies show that what appears in behaviour does not always show the attitude. Likewise, a person's attitude is not always reflected in his behaviour (Fatmanuraini, 2011).

Attitudes are generally characterised along the psychological and behavioural lines. Attitudes in other discipline (e.g. social science, cognitive psychology and social studies) have been studied and their character has been defined in various ways, due to the variety of different fields (Santello, 2013). Behaviour is an essential means for people for externalising knowledge from their psychological structures to their external world (Uher, 2016). Behaviourists view behaviour as a social, hence observable, which is therefore measurable. Thus Fasold (1985) describes the attitude's mentalist view as cognitive. Mentalists typically describe attitude as a mental response to a particular situation. It may be interpreted at cognitive, experiential and ideational level (Halliday, 2005).

Attitudes play a significant role in defining our view of the environment. They affect our perception of the world around us and decide how we respond to different entities around the world. Considering the critical role of attitudes in our lives, it is no surprise to learn that attitude studies have a long history (Oppenheim, 1998). Various researchers from many different perspectives and dimensions have identified and discussed them. The following sections contain a short overview of these viewpoints. The term attitude was described in various ways and from several angles.

The Psychology Encyclopedia describes the attitude model, based on three factors: affective, behavioural and cognitive, with minor adjustment. Therefore, an emotional reaction to specific individuals is a dominant feature of attitude. Attitude predicts not only behavioural patterns but also causes specific behavioural manifestations. Therefore, one of these manifestations takes the form of culture (Speilberger, 2004).

Language behaviour and attitude towards language are the two things that are closely related, which can determine the choice of languages as well as the survival of a language. . In the same way, appeals to language attitudes as an explanatory factor in change remain a wealth of sociolinguistics studies, which rely heavily on social-psychological theories and context in the development of approaches to interpersonal 
communication and groups (Kasstan, Auer \& Salmons, 2018). Language behaviour is the person's mental attitude in selecting and using language (Chaer \& Agustina, 2004). Kartomiharjo (1988) stated that basically, a person is free to choose a language and use it. This freedom is a part of human rights.

Although a person is free to choose and use language, even more in this globalization era, we still have to realise what was reminded by Kamaruddin (1989), in this globalization era we are buffeted by the compelling concept and foreign vocabulary, linguistic tools, code-switching, code-mixing, absorption, and transfer. However, we will not give up on foreign cultural domination.

This whole discussion of language, culture and attitudes leads one to believe that pupils have different attitudes towards the teaching of the target language culture. Cultural education has gone a long way from a target language to the recent change towards local culture education. This change requires an understanding of the native cultures of learners. This understanding occurs in multi-ethnic courses focused on cultural awareness of basic human rights and recognition (Bryam, 2004). In the current situation, these strategies are especially useful when cultural intolerance rises. Freeman and Freeman (1998) advocate incorporating learners' culture in the target language teaching as a way to improve learners' attitude and boost their self-confidence. The voices that rely on the use of local culture are also getting louder. There have been efforts to create new teaching content or to adapt current literature to suit the culture of the learner.

Language attitude is a person's mental position towards their own language or other's language (Kridalaksana, 2001). Attitude towards language is one's opinion or perception of a language, whether likes or not on the language, so the attitude influences the selection of the languages (Modiano, 2001). Lambert in Fatmanuraini (2011) stated that the attitude consists of three components, namely cognitive component, affective component, and conative component. The three components will be discussed in detail.

The cognitive component related to knowledge and ideas that are used in the process of thinking. Affective component concerns the matter of judgment like or dislike about something. Conative component concerning the behaviour or acts as a final decision. Through this component, people usually try to guess how a person's attitude to the circumstances they faced. These three components generally closely relate to one another.

Anderson in (Fatmanuraini, 2011) divided the attitude into two kinds, namely (1) linguistic attitude and (2) nonlinguistic attitude. Linguistic attitude can be categorised into a positive attitude and a negative attitude. A positive attitude is the person's enthusiasm toward the use of language that is used by the society where he or she lives. On the other hands, a negative attitude is disappearance or the weakness of the speakers' enthusiasm in using their own language. Non-linguistic attitude covers political attitude, religious attitude, and so on. It is the system of belief or cognition, about language, the object of language, which gives a personal tendency to react in a certain way. Non-linguistic attitude also can be positive and negative.

Garvin dan Mathiot in Chaer \& Agustina (2004) suggested that attitude toward language contains three main characteristics, namely:

a) Language loyalty

Language loyalty in people's desire to support that language, to preserve the language, even prevent it from the influence of other languages.

\section{b) Language pride}

Language pride encourages the use of that language to make it as a marker of identity, the symbol of the identity, and unity of the people.

c) Awareness of the norm

It tends to encourage people to use the language carefully and in courtesy.

\section{Conclusion}

The attitude of the language is essential in relation to a language because language attitudes can continue the living of a language. Attitude toward language is someone's mental attitude or feelings towards the position of their own language or other's languages. The language attitude also can be defined as the opinion or perceptions of a language, whether like or not against the language, so the attitudes influence language selection.

The process of attitude formation towards language is not far from the process of attitude formation in general. The attitude consists of three components, namely cognitive component, affective component, and conative component. The attitude can be divided into two kinds, namely linguistic attitude and nonlinguistic attitude. There are two categories of language attitude, positive attitude and negative attitude. Attitude toward language contains three main characteristics; those are language loyalty, language pride, and awareness of the norm.Linguistic perspective on the attitude towards language is that Sociolinguistics views the phenomena of language selection as social facts. Thus, the study of sociolinguistics is addressing the phenomena of language selection as a discourse in the event of communication and demonstrating the social and cultural identity of the speech participants. In daily interactions, community members are continually 
changing variations in the use of language. In a state, applies the use of bilingual, and every individual knows more than one language. In a bilingual or multilingual society, people must choose which languages should be used.

\section{References}

Brenzinger, M. (2017). Language contact and language displacement. The handbook of sociolinguistics, 271-284. Wiley: Blackwell.

Byram, M., \& Hu, A. (2013). Routledge encyclopedia of language teaching and learning. Routledge.

Chaer, A., \& Agustina, L. (2004). Sosiolinguistik: perkenalan awal. Penerbit PT Rineka Cipta.

Derin, T., Nursafira, M. S., Yudar, R. S., Gowasa, N. S., \& Hamuddin, B. (2020). Persuasive Communication: What Do Existing Literature Tells Us About Persuasive Communication Among Students?. Utamax: Journal of Ultimate Research and Trends in Education, 2(1), 12-18.

Downes, W. (1984). Language and society. Cambridge: Cambridge University Press.

Elyana. (2012). Pemilihan bahasa dalam masyarakat. Retrieved March 11, 2016, from http://elyanalie.blogspot.com/2012/03/pemilihan-bahasadalam-masyarakat.html.

Fasold, R. (1985). The sociolinguistics of society. Wiley: Blackwell.

Fatmanuraini. (2011). Sikap bahasa dan pemilihan bahasa. Retrieved March 12, 2016, from http://tianfatmanuraini.blogspot.com/2011/06/s ikap-bahasa-dan-pemilihan-bahasa-oleh.html.

Ferguson, C. A. (1999). Sociolinguistic perspectives: Papers on language in society. Language and Society, 28(4).

Freeman, Y. S., \& Freeman, D. E. (1998). ESL/EFL teaching: Principles for success (pp. 31-45). Portsmouth, NH: Heinemann.

Halliday, M. A. K., \& Matthiessen, C. M. (2013). Halliday's introduction to functional grammar. Routledge.

Hudson, R. A. (1985). Invitation to linguistics. Oxford: Blackwell.

Jabeen, F. (2011). The role of culture in ELT: Learners' attitude towards the teaching of target language culture. European Journal of Social Sciences, 23(4). 604-613

Kamaruddin. (1989). Kedwibahasaan dan pendidikan dwibahasa (Pengantar). Jakarta: Depdikbud.

Kartomiharjo, S. (1988). Bahasa cermin kehidupan masyarakat. Jakarta: Dikbud.
Kasstan, J. R., Auer, A., \& Salmons, J. (2018). Heritage-language speakers: Theoretical and empirical challenges on sociolinguistic attitudes and prestige.

Keraf, G. (1997). Komposisi. Flores: Nusa Indah.

Kondrateva, I. G., Madakina, N. Y., Sigal, N. G., \& Valeev, A. A. (2016). The development of the student as a person of culture in the context of multicultural education in non-language high school by means of a foreign language. International Electronic Journal of Mathematics Education, 11(1), 57-69.

Kridalaksana, H. (2001). Kamus linguistik. Jakarta: PT. Gramedia Pustaka Utama.

Marwa, M. (2014). Reasons for Students' CodeSwitching Between Informal Indonesian and English in ELT Contexts. ELT-Lectura, 1(1).

Mesthrie, R., Swann, J., Deumert, A., \& Leap, W. L. (2000). Introducing sociolinguistics. Edinburgh: Edinburgh University Press.

Modiano, M. (2001). Ideology and the ELT practitioner. International Journal of Applied Linguistics, 11(2), 159-173.

Mondada, L. (2016). Challenges of multimodality: Language and the body in social interaction. Journal of sociolinguistics, 20(3), 336-366.

Oppenheim, A. N. (2000). Questionnaire design, interviewing and attitude measurement. Bloomsbury Publishing.

Santello, M. (2015). Bilingual idiosyncratic dimensions of language attitudes. International Journal of Bilingual Education and Bilingualism, 18(1), 1-25.

Speilberger, C. D. (Ed.). (2004). Encyclopedia of applied psychology, 1. San Diego: Academic Press.

Uher, J. (2016). What is behaviour? And (when) is language behaviour? A metatheoretical definition. Journal for the Theory of Social Behaviour, 46(4), 475-501.

Verhoeven, L. (2017). Sociolinguistics and education. The handbook of sociolinguistics, 387-404. Wiley: Blackwell. 